\title{
AERODYNAMIC OPTIMISATION OF DEVELOPED LAND SUSTAINABLE TOWER ISLAND
}

\section{AERODYNAMICZNA OPTYMALIZACJA ZABUDOWY. ZRÓWNOWAŻONA WYSPA WIEŻ}

\author{
Mieczysław Kozaczko \\ PhD Architect \\ Author's Orcid number: 0000-0003-1252-8796
}

\section{Sławomir Rosolski}

PhD Architect, Associate Professor

Author's Orcid number: 0000-0001-9529-0423

Poznań University of Technology / Poland

Faculty of Architecture

\begin{abstract}
Economic and usable benefits from the proper land development may be programmed as early as at the stage of designing by forming structures that are both economic and comfortable, which is in accordance with assumptions of architechnology. This work presents the method of calculating particular aerodynamic parameters of the urban complex Sustainable Tower Island in KobylnicaLigowiec. The article analyses the wind speed and its pressure on walls of buildings depending on the height above ground level. Knowing these parameters allows optimisation of the location of devices collecting energy from renewable energy sources.
\end{abstract}

Key words: Architechnology, urban aerodynamics, wind energy, location of power generators.

\section{STRESZCZENIE}

Korzyści ekonomiczno-użytkowe wynikające z odpowiedniej zabudowy można programować już w fazie projektowania, kształtując struktury i ekonomiczne, i komfortowe - zgodnie z założeniami architechnologii. W niniejszym opracowaniu omówiono metodę obliczania niektórych parametrów aerodynamicznych zespołu urbanistycznego „Wyspa wież” w Kobylnicy-Ligowcu1. W artykule rozpatruje się prędkość wiatru i siłę jego naporu na ściany budynków w zależności od wysokości nad poziomem terenu. Znajomość tych parametrów pozwala na optymalizację rozmieszczenia urządzeń pozyskujących energię z OZE.

Słowa kluczowe: aerodynamika urbanistyczna, energia wiatru, lokalizacja generatorów energii.

\footnotetext{
${ }^{1}$ Rosolski S. et al., 2019
} 


\section{ASSUMPTIONS OF URBAN AERODYNAMICS}

Significant height and low percentage of the designed development create opportunities for effective use of moving masses of air by a properly designed urban layout. The speed of wind is the prime parameter that determines numerous beneficial phenomena. Once the speed of wind is known, it is easy to calculate its derivatives, such as wind pressure on walls (including working elements of energy converters), the amount of filtered air pollution or water collected from air (within defined time units). Basing on urban aerodynamics, architechnology ${ }^{2}$ can effectively apply new tools of optimisation of architectural composition.

Urban aerodynamics is based on methodology applied in meteorology. It may be used to calculate average speed of wind blowing within the structure at a certain height [Kozaczko 2018]. Wind pressure is the derivative of wind speed. Both these parameters are essential from the point of view of energy and economy, and therefore, they are the subject hereof. They refer to average values of wind speed and pressure calculated for the particular urban layout. Knowing these parameters at a certain height in the designed layout makes it possible to e.g. optimise the system of energy collection by placing wind generators in proper locations (taking into consideration the changing direction of air mass movement through that structure). The analysed urban layout is presented in Figure 1.

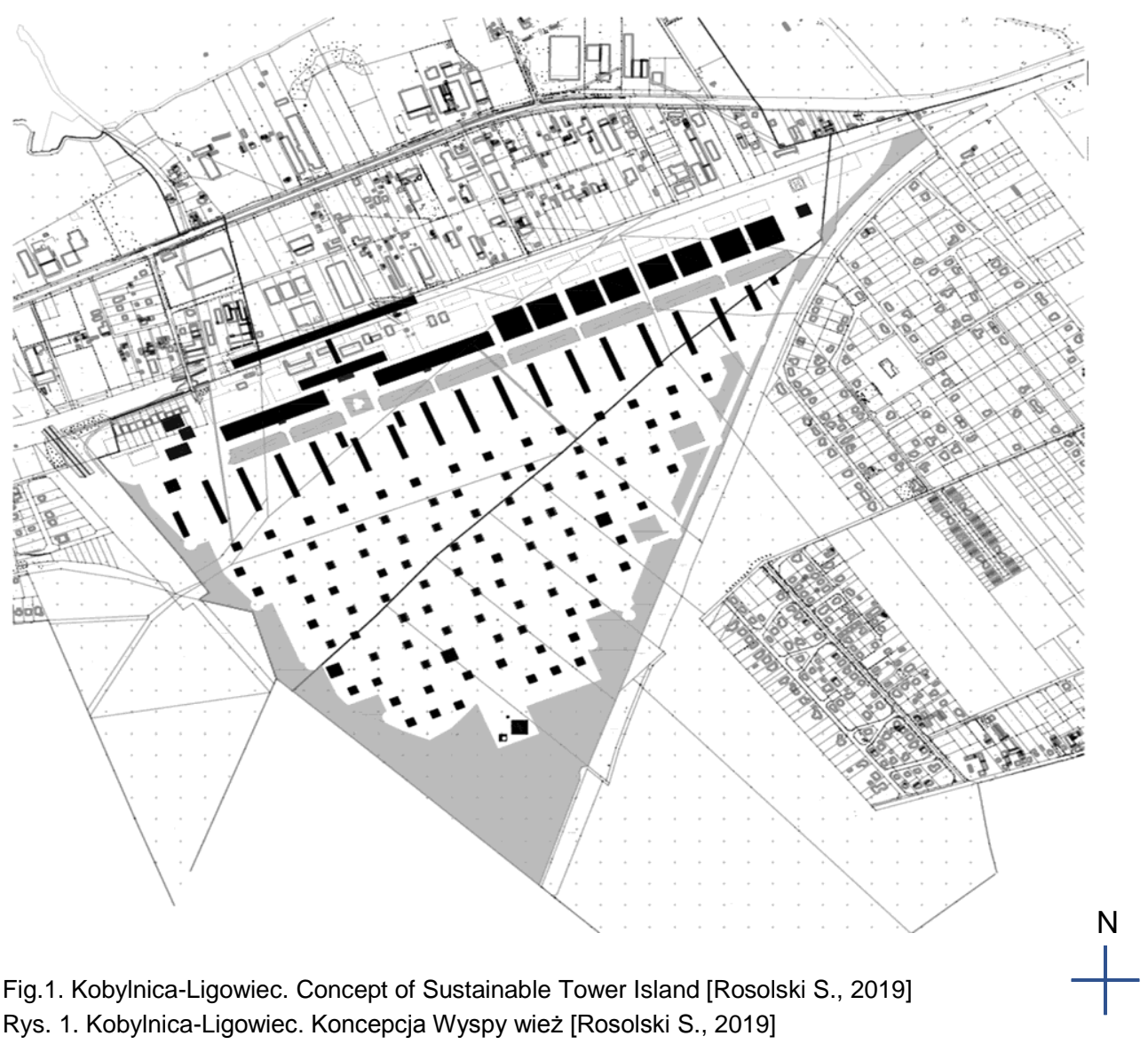

\footnotetext{
${ }^{2}$ Architechnology (Author's definition): scientific discipline creating interdisciplinary knowledge based on integration of achievements of contemporary architecture, construction, environmental engineering, economics, sociology, psychology and ecology reflecting the strategy of sustainable development.
} 
In case of tall buildings, the foot layer of the so called gradient wind (which is essential for calculations and is also a multiple of the height of the analysed complex) is located at the height which is a multiple of the structure height. That is why it can reach up to $300-500 \mathrm{~m}$. The gradient wind is a reference point for calculation of wind speed that significantly reduces when the flow proceeds downstream. The decrease of speed progresses according to the norms defining the so called vertical wind profile. It is characteristic for the particular land development and other elements of infrastructure that complement the urban composition.

\section{AVERAGE WIND SPEED IN THE ANALYSED STRUCTURE}

The calculation was based on the following average output parameters of wind in KobylnicaLigowiec (obtained on the basis of long-term weather forecasts): SW wind direction, output speed 5 $\mathrm{m} / \mathrm{s}=3^{\circ} \mathrm{B}$ (moderate wind according to Beaufort scale). Certainly, this is the speed of wind that is not disturbed by any land development, i.e. the wind that blows high (the gradient wind). The wind in the analysed structure will blow with different speed: starting from the foot layer, it will decrease downstream and reach its minimum just above ground.

\section{STARTING POINT: WIND SPEED AT THE STANDARD HEIGHT}

Having calculated the speed of the gradient wind in Kobylnica-Ligowiec, it is possible to calculate the speed Vs of the wind blowing in the analysed structure of Sustainable Tower Island at the standard height $h_{s}$, which was assumed at $10 \mathrm{~m}$ above ground level [Lorenc 1992]. The speed is defined in the following equation: $V_{s}=V_{G}\left(h_{S} / H_{G}\right)^{\alpha L}$, where $V_{s}$ is the wind speed at the standard height hs (which is a reference point for calculations), $V_{G}$ is the speed of the gradient wind (here: $V_{G}=5 \mathrm{~m} / \mathrm{s}$ ), $\mathrm{H}_{\mathrm{G}}$ is the foot layer of the gradient wind (the lowest characteristic height for a given land, empirically substantiated, where there are no wind disturbances caused by the landform) and $\alpha \mathrm{L}$ is an exponent depending on the so called class of terrain roughness ${ }^{3}$.

\section{WIND SPEED AT ANY HEIGHT}

Once Vs at the standard height $h_{s}$ is specified, it is possible to calculate the wind speed $v$ at any height above ground (the speed in various terrains is presented in Table 2).

The calculation is based on a power-law equation ${ }^{4}$. It is used to define the wind speed $v$ at any height $h$ in the surrounding with aerodynamic characteristics $\alpha$ :

$$
\mathrm{V}=\mathrm{V}_{\mathrm{s}}\left(\mathrm{h} / \mathrm{h}_{\mathrm{s}}\right)^{\alpha}
$$

where $h$ is height above ground, $h_{s}$ is the standard height $=10 \mathrm{~m}, v$ is the wind speed [m/s] at height $h, V_{s}$ is the wind speed $[\mathrm{m} / \mathrm{s}]$ at the height $=10 \mathrm{~m}, \alpha=0.24+0.096 \log \left(\mathrm{z}_{0}\right)+0.016\left(\log \mathrm{z}_{0}\right)^{2}$; the variable $z_{0}$ is the terrain roughness index [Regulation of the Minister of Environment, December 5 , 2002] and depends on the type of urban structure. Values applied in calculating the wind speed according to the power-law equasion are presented in Table 1.

\footnotetext{
${ }^{3}$ The wind speed depends on such structure parameters as percent coverage of the terrain $(p c)$ correlating with variable height of structures. In applied aerodynamics, the set of those spatial features of the structure is defined as the parameter of terrain roughness [Gumuła et al. 2006, Lorenc op.cit.].

${ }^{4}$ Power-law equation is also called Archibald's Law [Kopcewicz 1959, Trepińska 2005]
} 
Tab.1 Standard types of development analysed in Kobylnica-Ligowiec (the terrain roughness index $\mathrm{z}_{0}$ and exponent a defined on the basis of Schedule 1 to [Regulation of the Minister of Environment, December 5, 2002] and the European Norm [EN 1991-1-4, 2005]; Source: N N527 348934).

\begin{tabular}{|l|l|l|l|l|}
\hline 1 & 2 & 3 & 4 & 5 \\
\hline Type of development & $\begin{array}{l}\text { Type of } \\
\text { terrain }\end{array}$ & $z_{0}$ index & $\begin{array}{l}\text { Exponent } \\
\alpha\end{array}$ & $\begin{array}{l}\text { Standard speed } \\
\mathrm{V}_{\mathrm{s}}[\mathrm{m} / \mathrm{s}]\end{array}$ \\
\hline Open area, low vegetation, single buildings & $\mathrm{O}$ & 0.05 & 0.142 & 2.358 \\
\hline $\begin{array}{l}\text { Medium-height buildings, in cities up to 10 thousand } \\
\text { residents }\end{array}$ & $\mathrm{K} 1$ & 2.0 & 0.27 & 1.166 \\
\hline Tall buildings, in cities up to 100-500 thousand residents & $\mathrm{K} 2$ & 3.0 & 0.289 & 0.724 \\
\hline
\end{tabular}

In Table 1, pursuant to Polish and European Norms ${ }^{5}$, there are three types of development to be considered (type 1: open area of the existing airport in Kobylnica-Ligowiec and types K1 and K2, which show significant discrepancies in the wind speed, depending on the qualification of the structure designed for Kobylnica-Ligowiec).

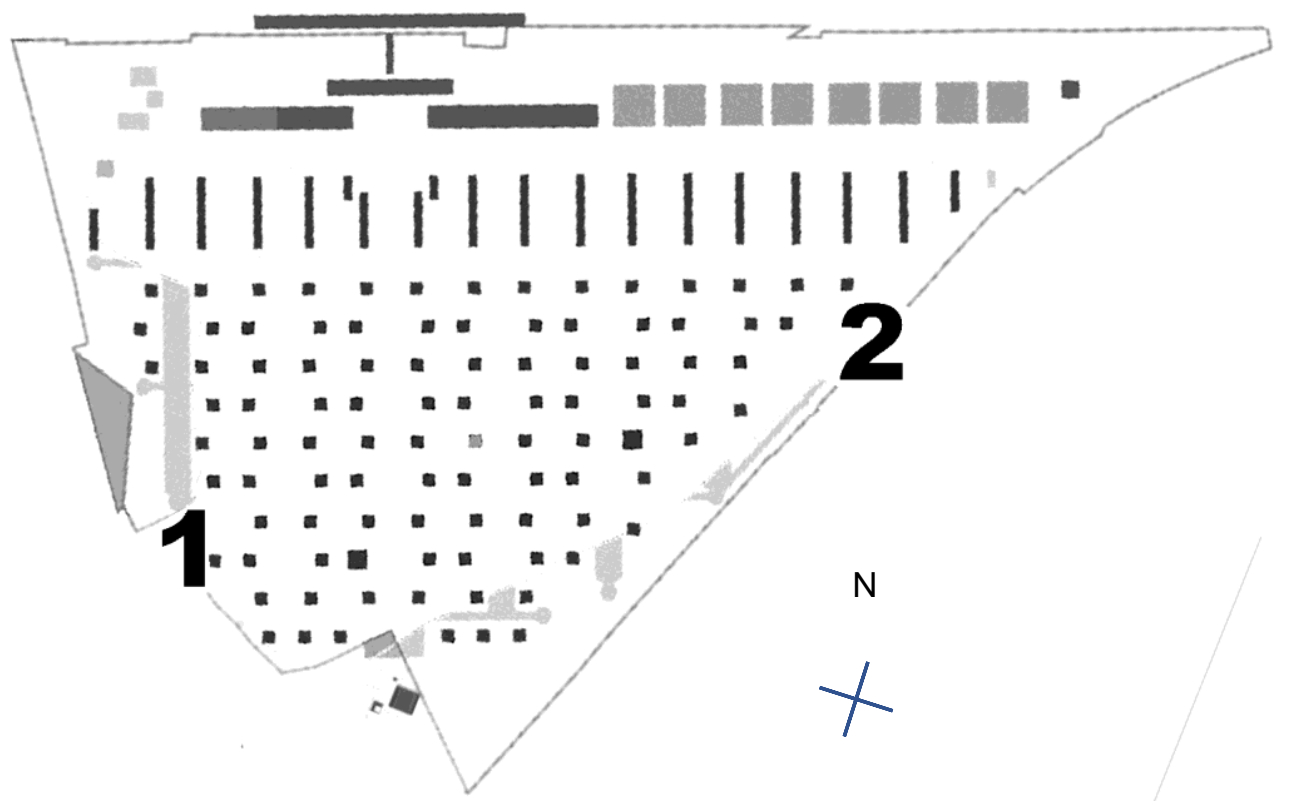

Fig. 2. Kobylnica-Ligowiec - urban layout. Two analysed locations (marked with numbers 1 and 2). An exemplary aerodynamic situation on October 20,2021: SW wind direction (from number 1 to number 2); wind speed at the hight $=1 \mathrm{~m}$ above ground: in location $1-1.7 \mathrm{~m} / \mathrm{s}$, in location 2 - between $0.63 \mathrm{~m} / \mathrm{s}$ and $0.37 \mathrm{~m} / \mathrm{s}$, speed of gradient wind $-5 \mathrm{~m} / \mathrm{s}$.

Rys. 2. Kobylnica-Ligowiec - układ urbanistyczny. Dwie analizowane lokalizacje (oznaczone dużymi cyframi 1 i 2). Przykładowa sytuacja aerodynamiczna z dnia 20 października 2021 r: kierunek wiatru SW (od cyfry 1 do cyfry 2); prędkość wiatru na wysokości $1 \mathrm{~m}$ nad terenem: w lokalizacji $1-1,7 \mathrm{~m} / \mathrm{s}$, w lokalizacji 2 - między 0,63 m/s a 0,37 m/s, prędkość wiatru gradientowego $-5 \mathrm{~m} / \mathrm{s}$

${ }^{5}$ Compare: European Norm EN 1991-1-4, 2005. 
Column 5 presents calculated wind speeds $V_{s}$ at the standard height of $10 \mathrm{~m}$ above ground ${ }^{6}$, attributed to particular, theoretical types of development. Formula (1) allows calculation of the speed of wind blowing in a certain type of terrain, at any height. Columns 2-7 in Table 2 compare calculated wind speeds for seven types of terrain stipulated in meteorology (where types 2-6 are city structures of A-E types and $\mathrm{O}, \mathrm{K} 1$ and $\mathrm{K} 2$ types reflect the analysed structure in KobylnicaLigowiec).

Wind speeds presented in columns 2-7 of Table 2 can be presented on a chart as so called vertical wind profiles (as in Fig. 3 - left side). The vertical wind profile provides data on the wind speed at the certain height above ground (profile coordinate $\mathrm{y}$ : height, profile coordinate $\mathrm{x}$ : wind speed at the "y" height)

Tab. 2 Wind speeds $v$ in various types of terrain at the height of 1, 25 and $55 \mathrm{~m}$ above ground. The darker font shows the analysed structure, the lighter font presents parameters calculated for other types of terrain: 2(A), 3(B) and 4(C) (source: $N$ N527 348934).

\begin{tabular}{|c|c|c|c|c|c|c|}
\hline 1 & 2 & 3 & 4 & 5 & 6 & 7 \\
\hline \multicolumn{7}{|c|}{ Wind speed } \\
\hline Type of terrain & \multirow[b]{2}{*}{$\mathrm{O}$} & \multirow[b]{2}{*}{$2(\mathrm{~A})$} & \multirow[b]{2}{*}{$3(\mathrm{~B})$} & \multirow[b]{2}{*}{4 (C) } & \multirow[b]{2}{*}{$\begin{array}{c}\mathrm{K} 1 \\
5(\mathrm{D})\end{array}$} & \multirow[b]{2}{*}{$\begin{array}{c}\mathrm{K} 2 \\
6(\mathrm{E})\end{array}$} \\
\hline $\mathbf{h}[\mathrm{m}] \boldsymbol{\nabla}$ & & & & & & \\
\hline 1 & 1.7 & 1.38 & 1.14 & 0.9 & 0.63 & 0.37 \\
\hline 25 & 2.69 & 2.57 & 2.27 & 1.94 & 1.49 & 0.94 \\
\hline 55 & 3 & 3 & 2.68 & 2.35 & 1.85 & 1.19 \\
\hline
\end{tabular}

\section{WIND PRESSURE IN THE ANALYSED STRUCTURE}

Once the wind speed profile in a given structure is known, it is possible to define the wind pressure on walls of buildings and other elements that can take advantage of it (e.g. wind turbines).

Tab. 3. Wind pressure $\Delta \mathrm{p}$ in various types of terrain at the height of 1, 25 and $55 \mathrm{~m}$ above ground. Source: N N527 348934.

\begin{tabular}{|c|c|c|c|c|c|c|}
\hline 1 & 2 & 3 & 4 & 5 & 6 & 7 \\
\hline & \multicolumn{6}{|c|}{ Wind pressure } \\
\hline $\begin{array}{l}\text { Type of } \\
\text { terrain }\end{array}$ & \multirow[t]{2}{*}{$\mathrm{O}$} & \multirow[t]{2}{*}{$2(\mathrm{~A})$} & \multirow[t]{2}{*}{$3(\mathrm{~B})$} & \multirow[t]{2}{*}{$4(\mathrm{C})$} & \multirow[t]{2}{*}{$5(\mathrm{~K} 1)$} & \multirow[t]{2}{*}{$6(\mathrm{~K} 2)$} \\
\hline $\mathrm{h}[\mathrm{m}] \boldsymbol{\nabla}$ & & & & & & \\
\hline 1 & 4.22 & 2.77 & 1.9 & 1.17 & 0.57 & 0.2 \\
\hline 25 & 10.5 & 9.66 & 7.5 & 5.51 & 3.25 & 1.3 \\
\hline 55 & 13.2 & 13.1 & 10.5 & 8.04 & 4.99 & 2.05 \\
\hline
\end{tabular}

Wind pressure $\Delta \mathrm{p}$ is calculated according to Weisbach-Hagen equation [Żenczykowski 1970, p. 87; 1987, p. 58]:

where

$$
\Delta \mathrm{p}=\mathrm{v}^{2} \xi \gamma / 2 \mathrm{~g}
$$

$\mathrm{v}$ is the wind speed at the height $\mathrm{h}$ in front of the barrier,

$\xi$ - constant aerodynamic coefficient (which equals 1.86 for facilities in the size of a single building and 1.25 for the whole or fragmentary city structure),

$\gamma$ is fixed value of air density and

$g$ is the universal gravitational constant.

\footnotetext{
${ }^{6}$ Bear in mind that the wind speed in all cases is $5 \mathrm{~m} / \mathrm{s}$.
} 
Hence, $\xi \gamma / 2 \mathrm{~g}$ has a fixed value of $21.72 \mathrm{~kg} / \mathrm{m}^{2} \cdot \mathrm{s}^{2}$ for a single building and $14.6 \mathrm{~kg} / \mathrm{m}^{2} \cdot \mathrm{s}^{2}$ for the whole city fabric. Table 3 presents values of wind pressure calculated according to WeisbachHagen equation.

Data from Tables 2 and 3 can be presented as charts (see Fig.3). It shows two groups of curves. The curves on the left are profiles of wind speed in various types of city structures, whereas curves on the right are profiles of wind pressure. The light font indicates particular types of terrain: 1, A-E.

Comparison of the values of wind pressure (the right side of the chart in Fig. 3) proves that on every tower from the south-western side (e.g. in location 1), at the height of about $60 \mathrm{~m}$ above ground, the amount of collected energy is six times larger than the amount of energy collected in location 2 (data from October 20, 2021).

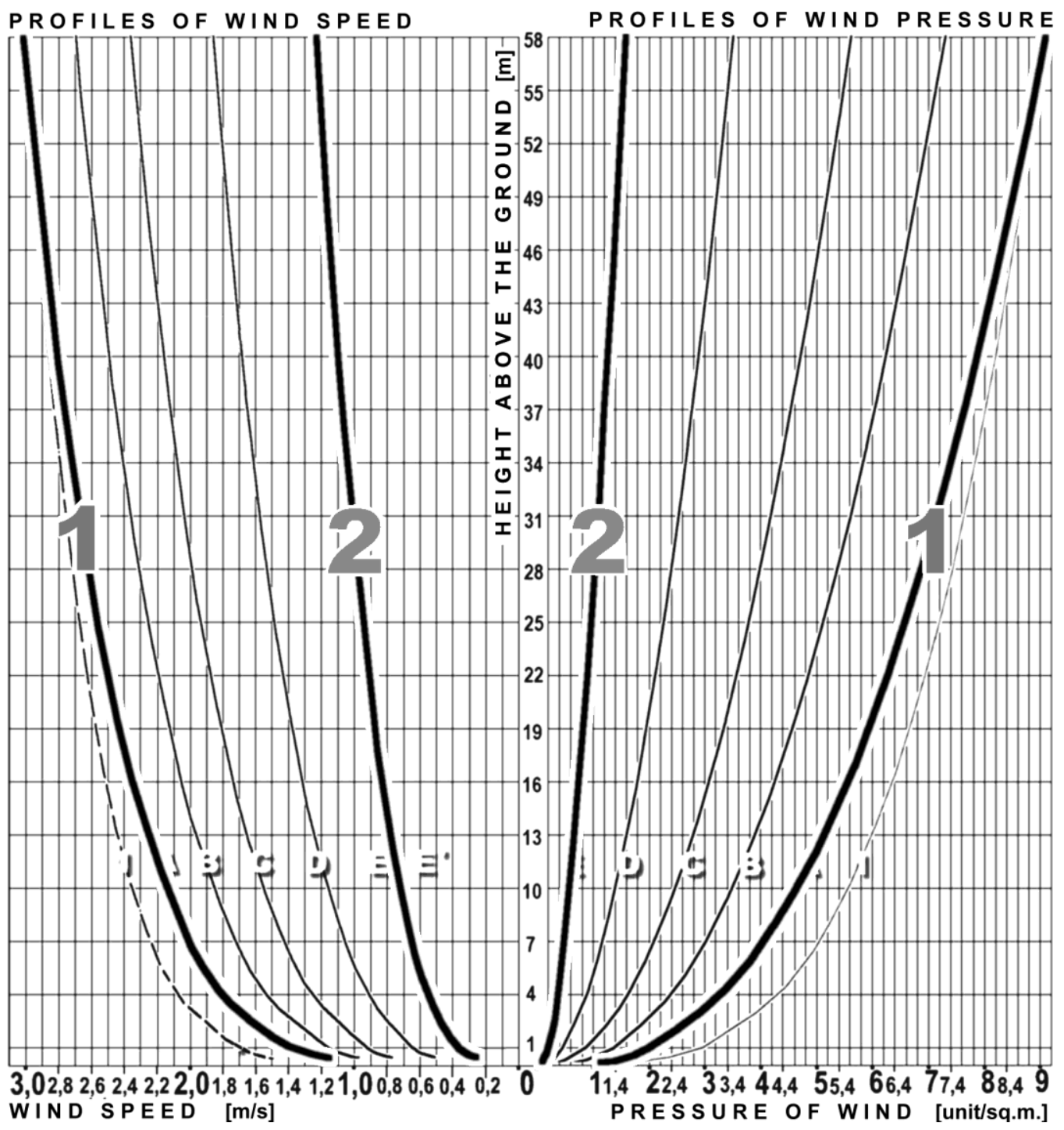

Fig.3. Profiles of wind speed and wind pressure in various types of city structures. Source: Arch N N527 348934, data: tables 2 and 3 . The $Y$ axis defines height at which the wind blows with speed and pressure of value defined on $X$ axis (speed - to the left, pressure - to the right; (source: N N527 348934). 
Profiles of wind speed and wind pressure in Kobylnica-Ligowiec are presented with bold lines marked with numbers 1 and 2 (respectively for locations 1 and 2 - see Fig. 2).

\section{SPECIFICS AND LIMITATIONS OF THE PROPOSED METHOD}

The above considerations refer to average wind speed and pressure in the whole analysed structure. As Fig. 4 shows, however, aerodynamic effects of forming an urban structure differ in places that are not located far away from each other. Charts on Fig. 4 present profiles of power available for systems relying on wind force. The composition of development accounts for the fact that in case of mild or moderate wind, the towers located on the windward edge of the whole layout are six times more efficient than the buildings inside the layout (in relation to the wind direction), located on the leeward edge. Since there are difficulties resulting from local fluctuations of wind pressure, the real air flow among buildings should be tested on scale models of the layout in order to obtain precise results for a given location. In particular, it is essential when an analysed layout departs from the typology applied in meteorology, as in the case of Kobylnica-Ligowiec.

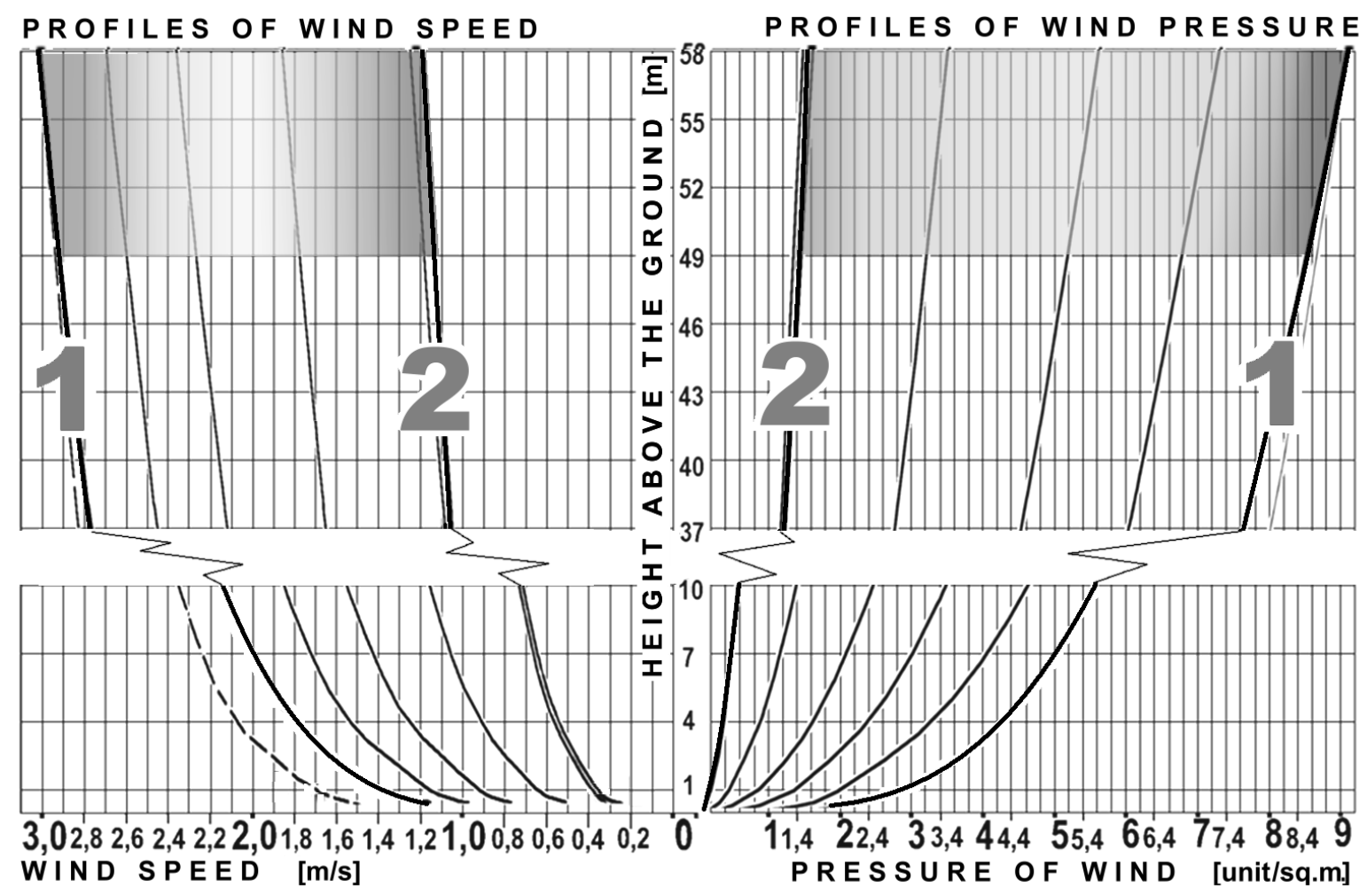

Fig. 4. Profiles of wind speed and available power obtained from wind (at two edges of the urban layout of Sustainable Tower Island in Kobylnica-Ligowiec; charts 1: towers on the windward edge, charts 2: towers inside the layout).

The area between the charts on Figure 4 shows the range of available power at the height of 50-60 $\mathrm{m}$ above ground. Undoubtedly, locating wind turbines on the edge of the layout would be more effective than placing them evenly in the whole area. However, the problem is far more complicated as it is not certain how the whole layout would react to strong winds that blow here quite often. In such cases the technical and acoustic regimes in which the turbines operate might be exceeded which would make the turbines stop in places where the wind is stronger and thus, exclude the greatest energy benefits. Certainly, in order to effectively manage wind power, it is necessary to empirically test and program the system, i.e. precisely calculate local wind speeds (in particular 
points of the urban layer). Thus, a device that will precisely program benefits of aerodynamics of Sustainable Tower Island in any location and with changing meteorological conditions seems to be a must.

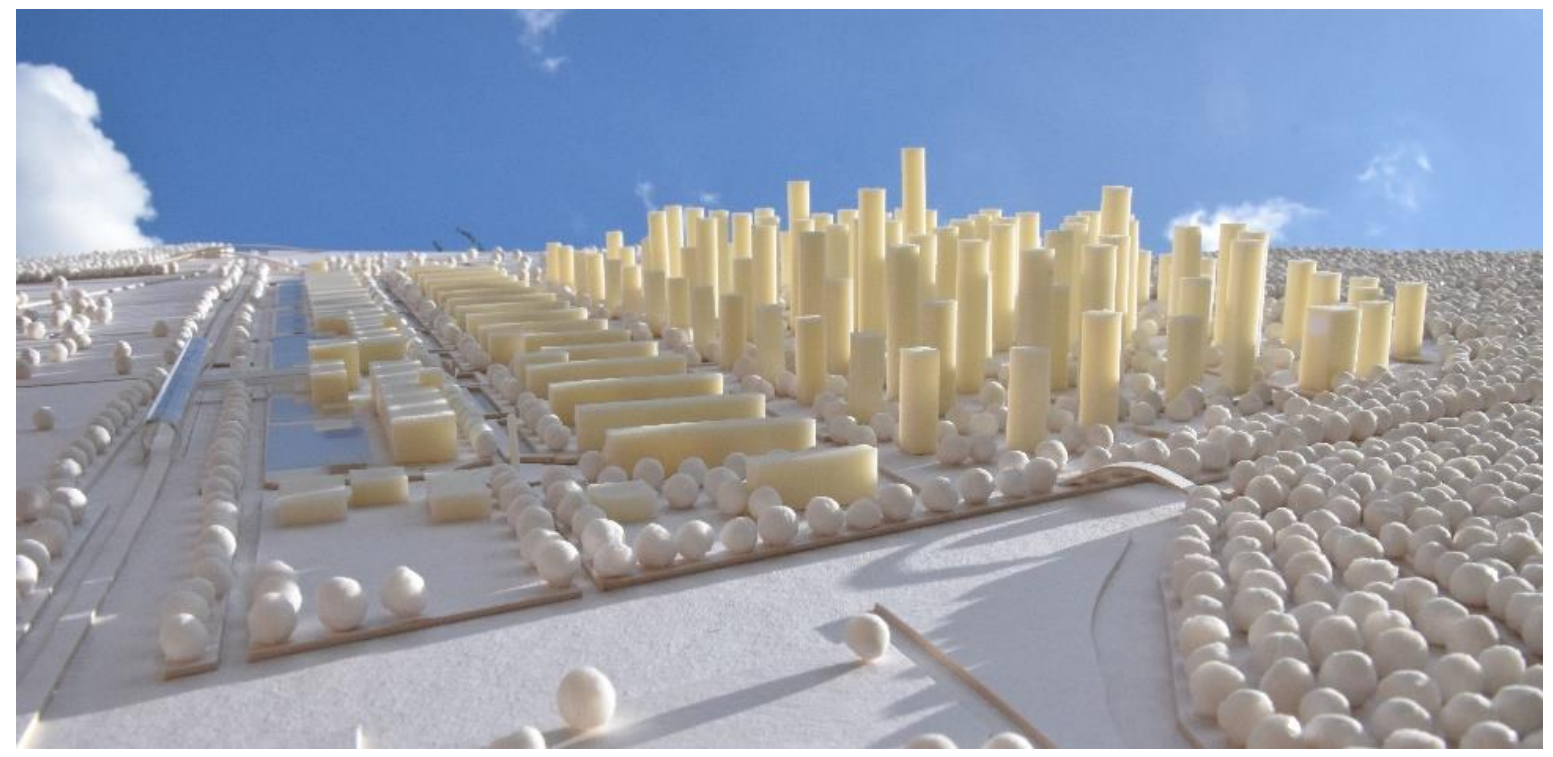

Fig. 5. Photo of the model of Tower Island. Source: archives of Autorska Pracownia Projektowa Sławomir Rosolski Architekt Rys. 5. Zdjęcie makiety Wyspy Wież. Źródło: archiwum Autorskiej Pracowni Projektowej Sławomir Rosolski Architekt

\section{SUMMARY}

Urban aerodynamics makes architechnology capable of using new tools of optimisation of architectural composition.

A properly programmed method of land development creates various ways of using wind power by the urban layout. Once the wind speed in the gradient layer is known, calculating other parameters is far easier. This includes, for example, the energy generated by the wind pressure on blades of generators which constitute an integral part of the urban structure. The location of generators can also be optimised - they can be located to create an effective system of power collection. Moreover, the degree of air purification from particulate matter (the weight of filtered pollution) could be precisely stipulated, which would be possible thanks to properly located elevation elements. Amount of water collected from air flowing through the structure can also be calculated, depending on applied technology.

Nevertheless, characteristic features of air (elasticity and density) cause chaotic turbulences which hinder metering of the particular structure. That is why theoretical calculations should be verified empirically. Methods of architechnology may be additionally empowered by proper tools which allow obtaining precise results at any point of the designed urban composition. ${ }^{7}$

\footnotetext{
${ }^{7}$ The concept of this tool is based on research conducted in the environment other than air, which is burdened by the existence of Kelvin-Helmholtz instability which would cause significant distortion of results of research conducted in nearly every wind tunnel (except for tunnels with cross sections of $25 \times 25 \mathrm{~m}$ or more)
} 


\section{AERODYNAMICZNA OPTYMALIZACJA ZABUDOWY. ZRÓWNOWAŻONA WYSPA WIEŻ}

\section{ZAŁOŻENIA AERODYNAMIKI URBANISTYCZNEJ}

Duża wysokość projektowanej zabudowy w powiązaniu z niewielkim procentem zabudowy stwarza szanse na efektywne wykorzystanie przemieszczających się mas powietrza przez odpowiednio zaprojektowany układ urbanistyczny. Parametrem pierwotnym, determinującym szereg pożytecznych zjawisk jest tu prędkość wiatru. Znając prędkość wiatru łatwo obliczyć jej pochodne, takie jak np. napór wiatru na ściany (w tym robocze elementy urządzeń konwertujących energię), a także ilość odfiltrowywanych z powietrza zanieczyszczeń lub ilość pozyskiwanej z powietrza wody (w określonych jednostkach czasu). Architechnologia ${ }^{8}$, za pomocą aerodynamiki urbanistycznej może skutecznie posługiwać się nowymi narzędziami optymalizacji kompozycji architektonicznej.

Za podstawę aerodynamiki urbanistycznej służy metodologia stosowana w meteorologii. Z jej użyciem można obliczyć średnią prędkość wiatru wiejącego w strukturze na pożądanej wysokości [Kozaczko 2018]. Z kolei pochodną prędkości wiatru jest jego siła parcia. Oba powyższe parametry, istotne choćby $z$ energetycznego i ekonomicznego punktu widzenia, są przedmiotem niniejszych dociekań. Dotyczą one średnich wartości prędkości i siły naporu wiatru, obliczonych dla konkretnego układu urbanistycznego. Znając oba parametry panujące na określonej wysokości w projektowanym układzie, można np. optymalizować system pozyskiwania energii, rozmieszczając we właściwy sposób generatory wiatrowe ( $z$ uwzględnieniem zmienności kierunku przepływu mas powietrza przez tę strukturę). Rozpatrywany układ urbanistyczny ukazano na rys. 1.

W przypadku zabudowy wysokiej, spód warstwy tzw. wiatru gradientowego (istotny dla obliczeń i stanowiący wielokrotność wysokości badanego zespołu) znajduje się na wysokości stanowiącej wielokrotność wysokości zabudowy. Może więc sięgać pułapu 300-500 m. Wiatr gradientowy stanowi punkt odniesienia dla obliczania prędkości wiatru, zmniejszającej się istotnie ku ziemi. To zmniejszanie prędkości postępuje według prawidłowości definiujących tzw. pionowy profil wiatru. Jest on charakterystyczny dla sposobu zabudowy oraz innych elementów urządzenia terenu, uzupełniających kompozycję urbanistyczną.

\section{2. ŚREDNIA PRĘDKOŚĆ WIATRU W BADANEJ STRUKTURZE}

Do obliczeń przyjęto następujące średnie wyjściowe parametry wiatru w Kobylnicy-Ligowcu (pozyskane na podstawie prognoz długoterminowych): kierunek $S W$, prędkość wyjściowa $5 \mathrm{~m} / \mathrm{s}=3^{\circ} B$ (wiatr umiarkowany wg Beauforta). Oczywiście jest to prędkość wiatru nie zakłócanego sposobem zagospodarowania przestrzeni, a więc wiejącego odpowiednio wysoko (zatem wiatru gradientowego). Ten wiatr wewnątrz badanej zabudowy będzie wiał z różną prędkością: poczynając od spodu warstwy gradientowej spada ona wraz z wysokością nad terenem, osiągając minimum tuż ponad ziemią.

\section{PUNKT WYJŚCIA: PRĘDKOŚĆ WIATRU NA WYSOKOŚCI STANDARDOWEJ}

Ustaliwszy prędkość wiatru gradientowego w Kobylnicy-Ligowcu, można obliczyć prędkość Vs wiatru wiejącego w badanej strukturze Wyspy wież na wysokości standardowej hs, którą ustalono na $10 \mathrm{~m}$ nad terenem [Lorenc 1992]. Prędkość tę określa zależność: $V_{S}=V_{G}\left(h_{s} / H_{G}\right)^{\alpha L}$, gdzie: $V_{s}$ prędkość wiatru na wysokości standardowej $h_{s}$ (stanowiącej punkt odniesienia w obliczeniach), $V_{G}$ - prędkość wiatru gradientowego (tu: $V_{G}=5 \mathrm{~m} / \mathrm{s}$ ), $\mathrm{H}_{\mathrm{G}}$ - spód warstwy wiatru gradientowego (ustaIona empirycznie najniższa charakterystyczna dla danego terenu wysokość, na której nie występu-

\footnotetext{
${ }^{8}$ Architechnologia (definicja Autora): specjalność naukowa kreująca interdyscyplinarną wiedzę opartą na zintegrowaniu osiągnięć współczesnej architektury, budownictwa, inżynierii środowiska, ekonomii, socjologii, psychologii i ekologii odpowiadającej strategii zrównoważonego rozwoju
} 
ją zakłócenia prędkości wiatru spowodowane ukształtowaniem tego terenu), aL - wykładnik potęgowy zależny od tzw. klasy szorstkości terenu9.

\section{PRĘDKOŚĆ WIATRU NA DOWOLNEJ WYSOKOŚCI}

Dysponując prędkością $V_{s}$ wiatru wiejącego na wysokości standardowej $h_{s}$ można obliczyć prędkość powietrza $v$ na dowolnym poziomie h powyżej podłoża (prędkości te - dla różnych warunków terenowych - zestawiono w tabeli 2).

Obliczenia umożliwia formuła potęgowa (power-law equation) ${ }^{10}$. Służy ona do określania prędkości wiatru v na dowolnej wysokości h w otoczeniu o charakterystyce aerodynamicznej $\alpha$ :

$$
\mathrm{V}=\mathrm{V}_{\mathrm{s}}\left(\mathrm{h} / \mathrm{h}_{\mathrm{s}}\right)^{\alpha}
$$

gdzie: $\mathrm{h}$ - wysokość nad terenem,

$\mathrm{h}_{\mathrm{s}}$ - wysokość standardowa wynosząca $10 \mathrm{~m}$,

$v$ - prędkość wiatru [m/s] na wysokości h,

$\mathrm{V}_{\mathrm{s}}$ - prędkość wiatru [m/s] na wysokości $10 \mathrm{~m}$,

$\alpha=0,24+0,096 \log \left(z_{0}\right)+0,016\left(\log z_{0}\right)^{2}$

zmienna $z_{0}$ to współczynnik aerodynamicznej szorstkości terenu [Rozporządzenie Ministra Środowiska 5.12.2002], zależny od typu struktury urbanistycznej. Wartości stosowane w obliczeniach prędkości v przy pomocy formuły Archibalda zawiera tabela 1.

Tab. 1. Standardowe typy pokrycia terenu, analizowane w Kobylnicy-Ligowcu (współczynnik aerodynamicznej szorstkości terenu $z_{0}$ oraz wykładnik a wyznaczony na podstawie załącznika nr 1 do [Rozp. Min. Środ. 5.12.2002] oraz normy europejskiej [EN 1991-1-4, 2005]; źródło: N N527 348934)

\begin{tabular}{|l|c|c|c|c|}
\hline \multicolumn{1}{|c|}{ Rodzaj pokrycia terenu } & 2 & 3 & 4 & 5 \\
\hline & Typ terenu & $\begin{array}{l}\text { Współczynnik } \\
\mathrm{z}_{0}\end{array}$ & Wykładnik $\quad \begin{array}{l}\text { 併弚k.standard.Vs } \\
{[\mathrm{m} / \mathrm{s}]}\end{array}$ \\
\hline teren otwarty, niska roślinność, pojedyncze budynki & $\mathrm{O}$ & 0,05 & 0,142 & 2,358 \\
\hline zabudowa średnia, w miastach do 10 tys. mieszk. & $\mathrm{K} 1$ & 2,0 & 0,27 & 1,166 \\
\hline zabudowa wysoka w miastach 100-500 tys. mieszk. & $\mathrm{K} 2$ & 3,0 & 0,289 & 0,724 \\
\hline
\end{tabular}

W tabeli 1 wyszczególniono, na podstawie normatywów polskich i europejskich ${ }^{11}$, trzy istotne tu typy pokrycia terenu (typ 1: otwarte tereny obecnego lotniska w Kobylnicy-Ligowcu oraz typy K1 i K2, wykazujące istotne rozbieżności w prędkości wiatru, w zależności od kwalifikacji projektowanej w Kobylnicy-Ligowcu struktury).

Dalej, poszczególnym - teoretycznym typom pokrycia terenu przyporządkowano wyliczoną prędkość wiatru Vs panującą na wysokości standardowej $10 \mathrm{~m}$ nad terenem (kolumna 5) ${ }^{12}$. Wzór (1) pozwala obliczyć prędkość wiatru wiejącego w określonym terenie, na dowolnej wysokości. W ta-

${ }^{9}$ Prędkość wiatru zależy od takich parametrów struktury jak wskaźnik pokrycia terenu pc (percent coverage), współdziałający wraz ze zmienną wysokością zabudowy. W aerodynamice stosowanej zespół tych przestrzennych cech struktury jest określany mianem parametru szorstkości terenu [Gumuła et al. 2006, Lorenc op. cit.].

${ }^{10}$ tzw. prawo Archibalda [Kopcewicz 1959, Trepińska 2005])

${ }_{11}$ Por. - Norma Europejska EN 1991-1-4, 2005

${ }^{12}$ Pamiętając o tym, że prędkość wiatru we wszystkich sytuacjach wynosi $5 \mathrm{~m} / \mathrm{s}$. 
beli 2 w kolumnach 2 - 7 zestawiono obliczone prędkości wiatru dla siedmiu typów terenu wyróżnionych w meteorologii (oznaczając typy 2-6 jako miejskie struktury typu A-E i wyróżniając typy O, K1 i K2 odpowiadające badanej strukturze w Kobylnicy-Ligowcu).

Prędkości wiatru z tabeli w kolumnach nr 2-7 można złożyć na wykresie w tzw. pionowe profile wiatru (jak na rys. 3 - strona lewa). Z profilu wiatru można odczytać, z jaką prędkością wieje wiatr na określonej wysokości nad ziemią.

Tab. 2. Prędkości wiatru v w różnych typach pokrycia terenu na wysokościach 1, 25 i 55 metrów nad terenem. Ciemniejsza czcionka dotyczy badanej struktury, czcionka jaśniejsza - to parametry wyliczone dla pozostałych typów pokrycia terenu: 2(A), 3(B) i 4(C) (źródło: N N527 348934)

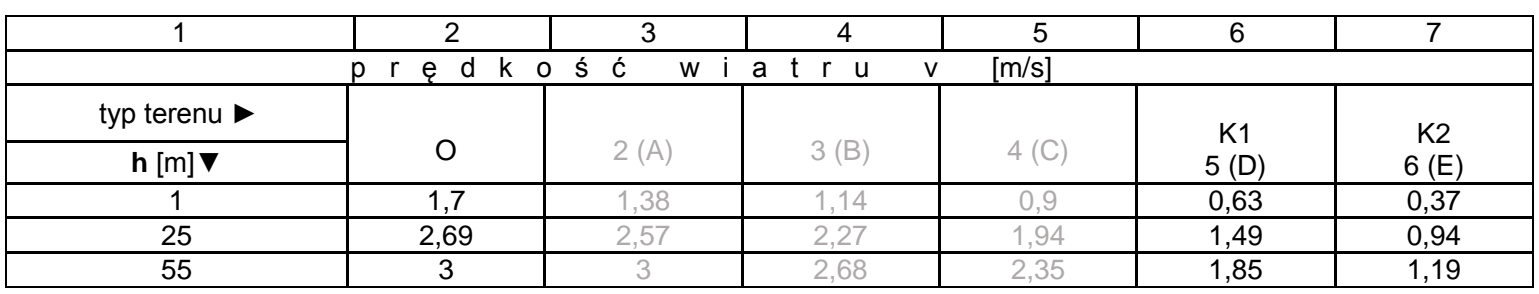

\section{SIŁA NAPORU WIATRU W BADANEJ STRUKTURZE}

Znając rozkład prędkości wiatru w danej strukturze można wyznaczyć napór wiatru na ściany budynków i inne elementy służące jego wykorzystaniu (np. turbiny wiatrowe).

Tab. 3. Siła naporu wiatru $\Delta \mathrm{p}$ w różnych typach pokrycia terenu na wysokościach 1, 25 i 55 metrów nad terenem (źródło: $\mathrm{N}$ N527 348934)

\begin{tabular}{|c|c|c|c|c|c|c|}
\hline 1 & 2 & 3 & 4 & 5 & 6 & 7 \\
\hline \multicolumn{7}{|c|}{ Siła naporu wiatru $\quad \mathrm{Dp} \quad[\mathrm{Pa}]$} \\
\hline typ terenu & \multirow[b]{2}{*}{$\mathrm{O}$} & \multirow[b]{2}{*}{$2(A)$} & \multirow[b]{2}{*}{$3(\mathrm{~B})$} & \multirow[b]{2}{*}{$4(\mathrm{C})$} & \multirow[b]{2}{*}{$5(\mathrm{~K} 1)$} & \multirow[b]{2}{*}{$6(\mathrm{~K} 2)$} \\
\hline $\mathrm{h}[\mathrm{m}] \mathbf{\nabla}$ & & & & & & \\
\hline 1 & 4,22 & 2,77 & 1,9 & 1,17 & 0,57 & 0,2 \\
\hline 25 & 10,5 & 9,66 & 7,5 & 5,51 & 3,25 & 1,3 \\
\hline 55 & 13,2 & 13,1 & 10,5 & 8,04 & 4,99 & 2,05 \\
\hline
\end{tabular}

Wielkość siły naporu wiatru $\Delta$ p określa wzór Weisbacha-Hagena (Żenczykowski 1970, s. 87; 1987, s. 58):

$$
\Delta \mathrm{p}=\mathrm{v}^{2} \xi \gamma / 2 \mathrm{~g}
$$

v oznacza tu prędkość wiatru na wysokości h przed przegrodą,

$\xi$ - stały współczynnik aerodynamiczny (przyjmujący dla obiektów wielkości pojedynczego budynku wartość 1,86, a dla całej tkanki miasta lub jej fragmentu - wartość 1,25),

$\gamma$ - stała gęstość powietrza,

g - stała wielkość przyspieszenia ziemskiego.

Zatem wyrażenie $\xi \gamma / 2 \mathrm{~g}$ ma stałą wartość $21,72 \mathrm{~kg} / \mathrm{m}^{2} \bullet \mathrm{s}^{2}$ dla pojedynczego budynku i $14,6 \mathrm{~kg} / \mathrm{m}^{2} \bullet \mathrm{s}^{2}$ dla całej tkanki miejskiej. W tabeli 3 zestawiono wartości siły naporu wiatru wyliczone ze wzoru Weisbacha - Hagena. 
Dane z tabeli 2 i 3 można złożyć w wykresy, jak na rysunku 3. Zawiera on dwie rodziny krzywych. Krzywe z lewej strony stanowią profile prędkości wiatru w różnych typach miejskich struktur, krzywe ze strony prawej to profile siły naporu wiatru. Jasną czcionką oznaczono poszczególne typy terenu: $1, \mathrm{~A}-\mathrm{E}$

Jak widać z porównania wartości siły naporu wiatru (rodzina profili po prawej stronie rys. nr 3), na każdej wieży od południowego zachodu (np. w lokalizacji 1) można na wysokości ok. $60 \mathrm{~m}$ nad terenem pozyskać sześciokrotnie więcej energii od energii pozyskanej w lokalizacji 2 - dane z dnia 20 października $2021 \mathrm{r}$.

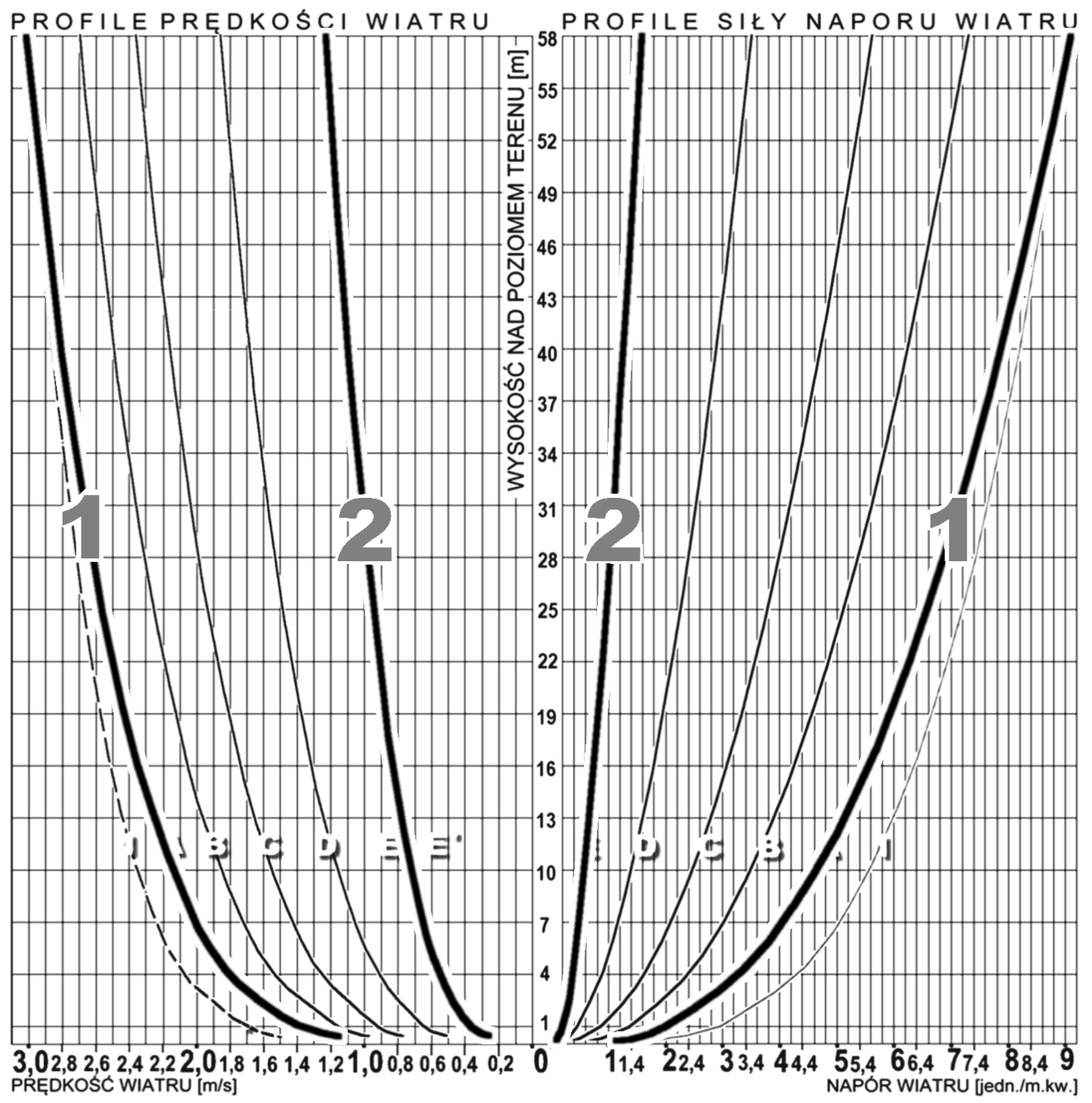

Rys. 3. Profile prędkości oraz siły naporu wiatru w różnych typach struktur miejskich. (źródło: [Arch. N N527 348934], dane - por. tab. 2 i 3 . Oś „y” określa wysokość, na której wieje wiatr z prędkością oraz siłą naporu o wartości wyznaczonej na osi „x” (prędkość - w lewo, napór - w prawo; (źródło: N N527 348934). 
Profile prędkości i naporu wiatru w Kobylnicy-Ligowcu ukazują pogrubione krzywe, oznaczone cyframi 1 i 2 (odpowiednio dla lokalizacji 1 i 2 - por. rys. 2)

\section{SPECYFIKA I OGRANICZENIA PROPONOWANEJ METODY}

Powyższe rozważania dotyczą średnich prędkości i naporu wiatru w całej badanej strukturze. Jednakże - jak widać na rys. 4 - aerodynamiczne skutki kształtowania struktury urbanistycznej różnią się między sobą w miejscach od siebie nieodległych. Wykresy na rys. 4 ukazują profile mocy dostępnej dla systemu wykorzystującego siłę wiatru. Kompozycja zabudowy powoduje, że wieże od nawietrznej, na obrzeżach całego układu są - w warunkach wiatru słabego lub umiarkowanego sześciokrotnie bardziej efektywne od budynków wewnątrz układu (w stosunku do kierunku wiatru), położonych na „zawietrznych” jego obrzeżach. Trudności wynikające z lokalnych fluktuacji ciśnienia wiatru powodują, że chcąc uzyskać precyzyjne dla danego miejsca wyniki, należy rzeczywisty przepływ powietrza między budynkami badać na pomniejszonych modelach zabudowy. Jest to istotne zwłaszcza w sytuacji, gdy analizowana forma zabudowy odbiega od typologii stosowanej w meteorologii, jak to ma miejsce w przypadku Kobylnicy-Ligowca.

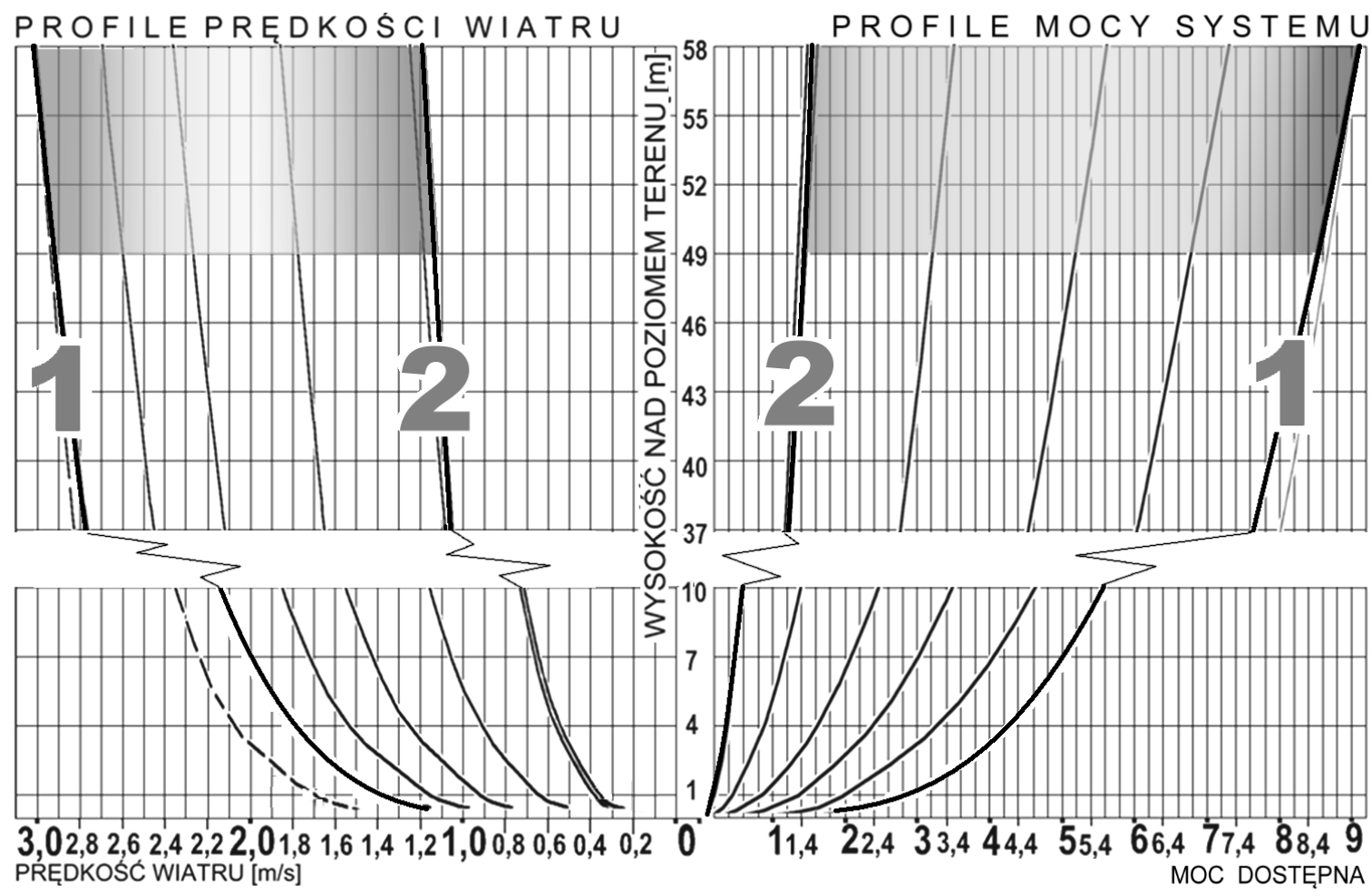

Rys. 4. Profile prędkości oraz dostępnej mocy pozyskiwanej z wiatru (w dwóch skrajnych lokalizacjach w urbanistycznym układzie Wyspy Wież w Kobylnicy-Ligowcu; wykresy 1 - wieże od nawietrznej, wykresy 2 - wieże w głębi układu).

Pole między wykresami na rys. 4 ukazuje rozpiętość dostępnej mocy na wysokości 50-60 m nad terenem. Z całą pewnością obrzeżna lokalizacja urządzeń energetycznych byłaby bardziej efektywna od równomiernego rozmieszczenia turbin wiatrowych w całym założeniu. Problem jest jednak bardziej skomplikowany. Nie wiadomo bowiem, jak zachowywałby się cały układ w nierzadkich tu sytuacjach, gdy wiatr jest silny. Wówczas reżimy technologiczno-akustyczne, w których mogą 
pracować turbiny nierzadko mogłyby być przekraczane, powodując wyłączenia urządzeń w miejscach silniejszego wiatru i wykluczając zarazem największe korzyści energetyczne. Z całą pewnością, chcąc efektywnie zarządzać energią pozyskiwaną z wiatru, konieczne staje się empiryczne sprawdzenie i programowanie systemu, polegające na precyzyjnym wyznaczaniu lokalnych prędkości wiatru ( $w$ danym punkcie urbanistycznego układu). Niezbędne staje się urządzenie, za pomocą którego można precyzyjnie programować korzyści płynące z aerodynamiki systemu Wyspy Wież w dowolnej lokalizacji oraz w zmiennych warunkach meteorologicznych.

\section{PODSUMOWANIE}

Architechnologia, za pomocą aerodynamiki urbanistycznej może skutecznie posługiwać się nowymi narzędziami optymalizacji kompozycji architektonicznej.

Odpowiednio zaprogramowany sposób zabudowy umożliwia wielorakie wykorzystanie energii wiatru przez układ urbanistyczny. Znając prędkość wiatru wiejącego w atmosferycznej warstwie gradientowej można łatwo obliczyć parametry, takie jak np. energię generowaną przez napór wiatru na łopatki generatorów, stanowiących integralne wyposażenie struktury urbanistycznej. Można także optymalizować sposób rozmieszczenia generatorów - składać je w efektywny system pozyskiwania energii. Dalej, można dokładnie określić stopień oczyszczania powietrza z cząstek stałych (masę odfiltrowywanych zanieczyszczeń), co następowałoby dzięki odpowiednio rozmieszczonym elementom elewacyjnym. Ponadto można wyliczyć ilość pozyskiwanej wody z powietrza przepływającego przez strukturę, w zależności od zastosowanej technologii.

Jednakże charakterystyczne cechy powietrza (sprężystość i gęstość) powodują chaotyczne turbulencje, co tworzy różne utrudnienia w opomiarowaniu konkretnej struktury. Z tego powodu obliczenia teoretyczne należy weryfikować empirycznie. Metody architechnologii można uzbroić w odpowiednie narzędzie, pozwalające na uzyskiwanie precyzyjnych wyników w dowolnym punkcie projektowanej kompozycji urbanistycznej ${ }^{13}$.

\section{BIBLIOGRAPHY}

Borysiewicz M., et al., Komputerowe modelowanie rozprzestrzeniania się skażeń w atmosferze, AND Sp. z 0.0., ISBN 83-903847-5-2., 1996.

EN 1991-1-4:2005. European Standard for Wind Actions on Structures, Brussels 2008. PN-EN 1991-1-4: 2008 Oddziaływania na konstrukcje - Część 1-4: Oddziaływania ogólne - Oddziaływania wiatru.

Frohn R.C., Remote Sensing for Landscape Ecology: New Metric Indicators for Monitoring, Modeling, and Assessment of Ecosystems, Lewis Publishers, Boca Raton, 1998.

Georgopoulos, P. G., and Seinfeld, J. H., Statistical Distributions of Air Pollution Concentrations, Environ. Sci. Technol. 16, 401A-416A., 1982.

Gumuła S., Knap T., Strzelczyk P., Szczerba Z., Energetyka wiatrowa, Uczelniane Wydawnictwa Naukowo Dydaktyczne, AGH, Kraków 2006.

Højstrup, J., A Simple Model for the Adjustment of Velocity Spectra in Unstable Conditions Downstream of an Abrupt Change in Roughness and Heat Flux. Bound.Layer Meteorol. 21, 341-356 1981.

\footnotetext{
${ }^{13}$ Koncepcja tego urządzenia opiera się na badaniach w środowisku innym, niż powietrze - obarczone występowaniem niestabilności Kelvina-Helmholtza. Niestabilności te przyczyniałyby się do znacznych zniekształceń wyników badań przeprowadzanych w niemal każdym tunelu aerodynamicznym (za wyjątkiem tuneli o przekrojach poprzecznych rzędu $25 \times 25$ m lub większym).
} 
Hunt, J. C. R., Simpson, J. E., Atmospheric Boundary Layers over Nonhomogenous Terrain. "Engineering Meteorology" (E. Plate, ed.), ss. 269-318. Elsevier, New York 1982.

Jarża A., Aktualne zagadnienia aerodynamiki atmosferycznej warstwy przyziemnej, materiały XIII Krajowej Konferencji Mechaniki Płynów, tom 3, 1998.

Kopcewicz T., Fizyka atmosfery, t.III, PWN, Warszawa 1959.

Kozaczko M., Energochłonność struktur urbanistycznych. Aerodynamika, Wyd. Sorus, 2017.

Kozaczko M., Aerodynamics of the City, Space \& Form / Przestrzeń i forma, 46/2021, Faculty of Architecture, ZUT Szczecin, ss. 103-116.

Kurowski M., Koherentna struktura wirów punktowych w zewnętrznym przepływie rozciągającym, UW Warszawa 2003.

Laskowski L., Wybrane zagadnienia fizyki miasta, Centralny Ośrodek Informacji Budownictwa, Warszawa 1987.

Linacre E., Climate Data and Resources, Routlege, London - New York 1992.

Lorenc H.: Zasoby wiatru w Polsce, Materiały badawcze IGIMW, Seria Meteorologia 18, Warszawa 1992.

Obuchowicz R., Wind Resources in the Urban Structure - CFD Numerical Analysis. Possibilities of Using Wind Energy on the Example of the Słoneczne Estate in Szczecin, Space \& Form / Przestrzeń i forma, 46/2021, Faculty of Architecture, ZUT Szczecin, ss. 147-164.

Panofsky, H. A., Larko, D., Lipschutz, R., Stone, G., Bradley, E. F., Bowen, A. J., and Højstrup, J., Spectra of Velocity Components over Complex Terrain, Q. J. R. Meteorol. Soc.108, 215-230, 1982.

Panofsky, H. A., Lenschaw, D. H., Wyngaard, J. C., The Characteristics of Turbulent Velocity Components in the Surface layer under Convective Conditions. Bound. Layer Meteorol. 11, 11977.

Projekt N N527 348934, archiwum Wydziału Architektury Politechniki Poznańskiej, Poznań 2012.

Rozporządzenie Ministra Środowiska z 14.11.2002 r. w sprawie szczegółowych warunków, jakim powinna odpowiadać prognoza oddziaływania na środowisko dotycząca projektów miejscowych planów zagospodarowania przestrzennego (Dz.U. nr 197, poz. 1667).

Rozporządzenie Ministra Środowiska z dnia 5 grudnia 2002 r. w sprawie wartości odniesienia dla niektórych substancji w powietrzu, Dz.U. 2003 nr 1 poz. 12.

Rosolski S., Projektowanie architektoniczne a zagadnienia odwrotne, Wydawnictwo Exemplum, Poznań 2012.

Rosolski S. et al., Opracowanie koncepcji programowo - przestrzenno-parametrycznej terenów lotniska w Swarzędzu, 2019.

Różycka W., Gacka -Grzesikiewicz E., Warunki klimatyczne a przestrzenna struktura miasta. Wybrane zagadnienia., COIB, Warszawa 1972.

Shimanuki, A., Formulation of a Vertical Distributions of Wind Velocity and Eddy Diffusivity Near the Ground, J. Meteorol. Soc. Jpn. 47, 292-298, 1969.

Sorbjan Z., Turbulencja i dyfuzja w dolnej atmosferze, PWN, Warszawa 1983.

Stunder B., Arya S., Windbreak Effectiveness For Storage Pile Fugitive Dust Control: A Wind Tunnel Study, Journal Of The Air Pollution Control Association,38:135-143, 1988.

Szymański E., O budowie kominów fabrycznych, Przegląd Techniczny t.XXXVI, Warszawa 1898.

Trepińska J., Pionowy profil prędkości wiatru przyziemnego, Folia Geographica, Series Geographica - Physica vol. XXXV - XXXVI $2004-2005$.

US EPA, Aggregate Handling And Storage Piles Aggregate Handling And Storage Piles, AP 42, vol. I, 13.2.4.1, US EPA Edition V, Jefferson City 2006.

Vugts, H. F., Cannemeijer, F., Measurements of Drag Coefficients and Roughness Length at a Sea-beach Interface, J. Appl. Meteorol. 20, 1981.

Zhdanov S. K., Nonlinear Theory of Kelvin-Helmholtz Instability, Moscow Engineering Physics Institute, 15409, Moskwa 2000.

Żenczykowski W., Budownictwo ogólne, tom IV, Arkady, Warszawa 1970.

Żenczykowski W., Budownictwo ogólne, tom 3/1, Arkady, Warszawa 1987.

Żurański J.: Obciążenia wiatrem budowli i konstrukcji, Wydawnictwo Arkady, Warszawa, 1978. 


\section{AUTHOR'S NOTE}

Mieczysław Kozaczko - The author's field of research is the issue of coherent architectural and urban composition.

Sławomir Rosolski - Author focuses his work and interests on designing NZEB constructions, passive constructions, integrated designs, construction in terms of ecological effectiveness and sustainable development. He is author of the theory of reciprocal aspects in architectural design and creator of a new scientific specialty - architechnology.

\section{O AUTORZE}

Mieczysław Kozaczko - Autor zajmuje się zagadnieniami spoistej kompozycji architektonicznej i urbanistycznej.

Sławomir Rosolski - Dorobek naukowy Autora oraz jego zainteresowania własne ukierunkowane są na obszary projektowania budownictwa niemal zeroenergetycznego, pasywnego, projektowania zintegrowanego, budownictwa w aspekcie efektywności ekologicznej i zrównoważonego rozwoju. Jest autorem teorii zagadnień odwrotnych w projektowaniu architektonicznym i kreatorem nowej specjalności naukowej - architechnologii.

Contact | Kontakt: mieczyslaw.kozaczko@put.poznan.pl; slawomir.rosolski@put.poznan.pl 